\title{
JESUS BANDIDO: MESSIANISMO POPULAR E BANDITISMO SOCIAL NO PERÍODO NEOTESTAMENTÁRIO BÍBLICO ${ }^{1}$
}

\section{The Outlawed Jesus: popular messianism and social banditry in the biblical neotestamentary period}

\author{
Basílio Henrique Pereira Júnior ${ }^{2}$ \\ Verner Hoefelmann ${ }^{3}$
}

\section{Resumo:}

A abordagem do Jesus histórico, através de uma ótica sociológica que priorize o diálogo com os movimentos populares no contexto histórico do Novo Testamento, é cada vez mais necessária. O contexto histórico-político-social do Messias é explorado, neste artigo, por meio dos aspectos antropológicos e epistemológicos. Sob a política vigente dos dias narrados no Novo Testamento, encontra-se uma outra face da sociedade palestina do início do século I d.C. Este artigo realiza um levantamento de informações sobre o ambiente político-social da Palestina judaica neste período, e analisa os aspectos do messianismo popular e banditismo social no Novo Testamento. Há indícios da ligação direta entre o Jesus histórico e a esperança messiânica judaica, tornando essas duas esferas inseparáveis na compreensão do texto sacro. Essa perspectiva mostra um Jesus que não só fez pregações de cunho religioso, mas personificou alguém que viveu e falou sobre a realidade social da sua época.

Palavras-chave: Banditismo Social. Movimentos Messiânicos. Jesus histórico.

\section{Abstract:}

The approach of the historical Jesus through a sociological perspective that prioritizes dialogue with popular movements in the historical context of the New Testament is increasingly necessary. The historical-political-social context of the Messiah is explored in this article through anthropological and epistemological aspects. Through a deepening of the current policy of the days narrated in the New Testament, another face of Palestinian society from the beginning of the first century $A D$ is found. This article surveys information on the politicalsocial environment of Jewish Palestine in this period and analyzes the aspects of popular messianism and social banditry in the New Testament. There is evidence of a direct link between the historical Jesus and the Jewish messianic hope, making them inseparable in understanding the sacred text. This perspective shows a Jesus who not only had lectures of a religious nature, but the personification of someone who lived and spoke about the social reality of his time.

Keywords: Jewish Palestine. Messianic movements. Historical Jesus.

1 Artigo Submetido em: 15.01.2019. Artigo Aceito em: 10.09.2020

2 Graduação em Fisioterapia e Teologia. Especialização em Teologia. Mestrando em Modelos de Decisão e Saúde pela Universidade Federal da Paraíba, PB. Contato: basiliofisioterapeuta@gmail.com

3 Graduação e Mestrado em Teologia. Professor da Faculdades EST. Contato: vernerhoe@hotmail.com

Protestantismo em Revista | São Leopoldo | v. 46, n. 01 | p. 134-147| Jan./jun. 2020

Disponível em: <http://periodicos.est.edu.br/index.php/nepp> 


\section{Introdução}

A Palestina do século I d.C. foi marcada por um cenário de desigualdades econômicas e sociais. A expectativa messiânica dos judeus por um líder político, que rompesse o jugo imposto pelos seus inimigos, e trouxesse de volta para Israel a centralização política e restauração religiosa dos anos davídicos, era cada vez mais inflamada pelos abusos de poder e confrontos religiosos.

Os movimentos religiosos não emergem fora do espectro político, sendo majoritariamente pragmático este comportamento. O surgimento do cristianismo ocorreu em um contexto de forças políticas e sociais, por isso, a legislação utilizada para assegurar propriedades e apropriações publicadas desde Roma vinculam-se às reações messiânicas.

A cultura helenista, representada pelos estrangeiros dominadores ptolomaicos, selêucidas e romanos, expôs o judaísmo a uma intensa corrente de assimilação cultural, religiosa e política. Nesse tempo, tanto os dirigentes da Galileia, quanto os da Judeia, procuravam mediante símbolos, aproximar o judaísmo da cultura helenística, a fim de integrálo mais rapidamente ao Império Romano.4

No confronto com essa situação, apresentando uma contracultura, surgem no judaísmo movimentos de renovação que se opunham a esse vórtice assimilativo. Essênios, fariseus, saduceus, militantes de resistência e movimentos proféticos de curta duração, são exemplos desse contexto palestino nos tempos de Jesus.

Apesar da aparente paz superficial, esses movimentos revolucionários surgem no cenário bíblico através da narrativa dos evangelhos, porém sua atuação não fica muito clara. 5 Existe uma série de eventos messiânicos na história do judaísmo, dentre esses movimentos surge o movimento messiânico de Jesus, conhecido por isso como o Messias. Ele realizou a sua atuação num período específico do século I d.C., numa época em que existiam outros movimentos messiânicos populares, alguns dos quais contemporâneos entre si, todos eles tendo vários elementos em comum. 6

Observa-se na literatura teológica, que a temática da sociedade judaica, no Novo Testamento, traz uma abordagem histórico-religiosa muito contundente. Existe uma ênfase dos acontecimentos Neotestamentários como cumprimento das profecias veterotestamentárias. Observa-se um período lacunoso sobre os fatos políticos e sociais que complementam o cenário histórico para uma melhor compreensão do texto sacro.

Neste sentido, surge a hipótese: um estudo sobre o contexto histórico-políticosocial, explorando aspectos antropológicos, epistemológicos e um aprofundamento sobre a política vigente dos dias narrados no Novo Testamento, poderia revelar uma outra face da sociedade palestina do século I d.C. e trazer novos elementos para uma melhor compreensão do texto bíblico?

Este trabalho propõe-se a realizar um levantamento histórico sobre o ambiente político-social da Palestina judaica, no início da Era Cristã, e analisar os aspectos do

4 THEISSEN, Gerd. A religião dos primeiros cristãos: Uma teoria do cristianismo primitivo. Tradução Paulo $\mathrm{F}$. Valério. 1a Edição. São Paulo: Paulinas, 2009, p.57.

5 THEISSEN, 2009, p. 58.

6 RIBEIRO, Ari Luís do Vale. Jesus e os movimentos messiânicos. Revista de Cultura Teológica, n. 66, p. 27-54, 2009. Disponível em: < http://www.scielo.br/pdf/his/v23n1-2/a12v2312.pdf> Acesso em: 07 jul 2019.

Protestantismo em Revista | São Leopoldo | v. 46, n. 01 | p. 134-147| Jan./jun. 2020

Disponível em: <http://periodicos.est.edu.br/index.php/nepp> 
messianismo popular e banditismo social ${ }^{7}$, no período Neotestamentário. Esses movimentos político-sociais foram uma realidade do século I d.C, porém, no texto sagrado, eles não estão expostos de maneira clara, o que dificulta o entendimento da narrativa bíblica, sendo esses peças-chave na reconstrução do cenário histórico do Novo Testamento.

\section{A Palestina Judaica subversiva: resistência social contra os abusos políticos e religiosos do Século I d.C.}

A Palestina judaica do primeiro século depois de Cristo, estava densamente dividida por desequilíbrios políticos e sociais que colocavam em risco a convivência em sociedade. Esses fatos se transformaram em conflitos muito violentos, que normalmente ocorriam entre os explorados, excluídos e oprimidos e os opressores e exploradores. Como na maioria dos países com economias emergentes hoje, na Palestina judaica havia uma minoria favorecida e beneficiada pelo poder político-público, às custas da grande maioria, a classe desfavorecida. ${ }^{8}$

Em meados do século I, calcula-se entre 50 e 80 milhões os habitantes do Império Romano, dos quais cerca de $90 \%$ viviam no campo. Porém a terra, a principal fonte de sobrevivência para a população do Império, inclusive aquela da Palestina, era muito mal distribuída. A camada rural enfrentava um quadro sombrio, destacando os pesados impostos a que era sujeitada. Em casos de fuga de camponeses para não pagarem impostos, suas famílias ou vizinhos eram brutalmente maltratados e mesmo torturados até a morte. ${ }^{9}$

A corrupção e o abuso de poder em qualquer sociedade buscam tornar-se mais fortes criando estratégias e táticas para perpetuar sua existência criminal. As assimetrias econômicosociais por meio de contrafação e descomedimento de poder também usam argumentos divinos para justificar e legitimar suas ações. Seus atores ousam até dizer que são perseguidos, tanto ideologicamente como politicamente. ${ }^{10}$

Os movimentos messiânicos populares vêm com um objetivo pré-político e préideológico ${ }^{11}$ em resposta às condições sub-humanas enfrentadas pelo povo judeu. Este fenômeno também ficou conhecido como "anti-reinado" e era um ato de protesto e

7 O conceito de banditismo social foi descrito por Hobsbawm (1959) através de um estudo comparativo sobre formas de resistência social nos séculos XIX e XX. O conceito refere-se aos "fora da lei", ou seja, os "banditistas" camponeses que podem ser encontrados em sociedades de estrutura agrária como reação à tradicional exploração social, desestabilização e opressão, motivadas por pesadas cargas tributárias governamentais, assim como por carestias ou crises sociais (STEGEMANN, Ekkehard W; STEGEMANN, Wolfgang. História Social do Protocristianismo: os primórdios do judaísmo e as comunidades de Cristo no mundo mediterrâneo. 1a ed. Paulus, Sinodal, São Paulo, 2004.).

8 WIESE, Werner. Conflitos sociais e esperança messiânica na Palestina judaica do século I d.c. Vox Scripturae. 12:1, FLT, 2009, p.25-50.

9 ROCHA, Ivan Esperança. Dominadores e dominados na Palestina do século I. História (São Paulo), p. 239-258, 2004. Disponível em: <http://www.scielo.br/pdf/his/v23n1-2/a12v2312> Acesso em: 02 jul 2019.

10 REIMER, Ivoni Richter. As bem-aventuranças como antídoto contra a dominação e corrupção. Ribla, v. 78, n. 2, p. 135-153, 2018. Disponível em: <https://www.metodista.br/revistas/revistasims/index.php/Ribla/article/view/8848> Acesso em 15 jul. 2019.

11 Os termos "pré-político" e "pré-ideológico" usados por Stegemann e Stegemann, 2004, p. 207, referem-se aos movimentos de resistência religioso-político e revolucionários-sociais presentes na Palestina do século I d.C., comandados em forma de protesto ao sistema romano-herodiano, motivados pela religião, entretanto politicamente conscientes.

Protestantismo em Revista | São Leopoldo | v. 46, n. 01 | p. 134-147| Jan./jun. 2020

Disponível em: <http://periodicos.est.edu.br/index.php/nepp> 
reprovação popular contra o domínio religioso-político, orientados por uma liderança carismática messiânica. ${ }^{12}$

Porém, essa ideia de Messias não surgiu aleatoriamente. Com o estabelecimento da monarquia israelita na literatura veterotestamentária, o messianismo assume a forma da monarquia política, e o próprio rei Davi, com sua dinastia, transforma-se no seu elemento determinante. $O$ rei representaria o povo, como ocorria em outras nações vizinhas, e através dele, o povo agiria com unidade política. ${ }^{13}$

A não diferenciação entre a autoridade política e a autoridade religiosa não era exclusividade dos judeus. Em Roma, isso era um hábito comum e o culto ao imperador, prática recorrente na Palestina judaica, reforçava na verdade um ato eminentemente político. ${ }^{14}$ Para Ângela Zitzke: "O Império Romano não diferenciava a autoridade política da religiosa, portanto, não prestar culto ao imperador era visto como uma ameaça a seu governo." 15

O autoritarismo romano alimenta, nos camponeses judeus, a esperança do cumprimento das profecias de um Messias restaurador e o reestabelecimento de Israel na economia política mundial. Eles não admitiam ser privados da sua liberdade do domínio opressivo estrangeiro e nacional. Sobre o que a autora asserta: "Mas, diante do Estado, autoridade santa e quase divina, não havia liberdade de vida privada. Seu poder de ação era total". ${ }^{16}$

Diante dessa realidade, era inevitável que houvesse antagonismos ao poder imperial regente na Judeia, alguns deles se deram através da violência armada. Quase todos os movimentos separatistas eram grupos populares dirigidos contra a elite judaica dominante e contra a dominação romana. ${ }^{17}$

A Palestina judaica, neste período, fornecia chão fértil para o surgimento de um movimento que mais tarde ficou conhecido como banditismo social. Não foi só a opressão política externa que forneceu as condições necessárias para o surgimento deste movimento. A exploração religiosa interna da aristocracia sacerdotal instalada e perpetuada com a construção do segundo templo, teve sua parcela de contribuição. Para garantir o funcionamento do templo, com seu enorme aparato em Jerusalém, os camponeses tinham a obrigação de entregar o dízimo. ${ }^{18}$ Porém, este não era o maior dos problemas dos judeus: a pesada carga tributária romana era um dos grandes defraudadores da sociedade judaica.

De um modo geral, o povo levava esta sua obrigação a sério: "até mesmo depois do começo da grande revolta, os judeus da Galileia voluntariamente entregaram seus tributos aos sacerdotes". ${ }^{19} \mathrm{Na}$ verdade, a população estava sob dupla tributação: romana e judaica.

12 STEGEMANN; STEGEMANN, 2004.

13 RIBEIRO, Ari Luís do Vale. Jesus e os movimentos messiânicos. Revista de Cultura Teológica, n. 66, p. 27-54, 2009. Disponível em: < http://www.scielo.br/pdf/his/v23n1-2/a12v2312.pdf> Acesso em: 07 jul 2019.

14 FONSECA, Luís Fernando. A secularização da utopia: as raízes do pensamento igualitário na cultura judaicocristã. São Leopoldo: EST/PPG, 2018. p.67.

15 ZITZKE, ÂNGELA, Amor Divino na Carta aos Romanos: análise histórica, exegética e sistemática da entrega de Cristo em textos selecionados. Tese de Doutorado. São Leopoldo: EST/PPG, 2011. p. 47.

16 ZITZKE, 2011, p. 74-75.

17 HORSLEY, Richard A.; HANSON, John S. Bandidos, Profetas e Messias: Movimentos Populares no Tempo de Jesus. 1ạ ed. São Paulo: Paulus, 1995.

18 WIESE, 2009. p.25-50.

19 HORSLEY; HANSON, 2009, p. 65.

Protestantismo em Revista | São Leopoldo | v. 46, n. 01 | p. 134-147| Jan./jun. 2020

Disponível em: <http://periodicos.est.edu.br/index.php/nepp> 
Diante disso, os banditistas atacavam especialmente a elite local da Galileia e não os camponeses. Ao contrário, com estes eles tinham uma relação muito boa. Os camponeses viam nos salteadores defensores da justiça e candidatos ao cargo de possíveis Messias, por isso os protegiam e estavam dispostos a sofrer as consequências desta proteção. ${ }^{20}$

Abordar o tema messianismo, seja na esfera religiosa ou histórico-política deste contexto palestino, acaba levando a um processo de desconstrução de saberes, especialmente quando se trata do messianismo e expectativas messiânicas que se alojaram no cenário judaico, no qual Jesus estava inserido ${ }^{21}$. Observa-se na narrativa dos evangelhos uma obscuridade sobre essa temática (afinal esse não era seu propósito primário), e que a história da Palestina necessita ser criticamente reexaminada para construção de uma base históricopolítica consolidada. ${ }^{22}$

Na verdade, é necessário compreender o meio político no qual Jesus nasceu e foi inserido, para uma melhor compreensão na narrativa bíblica. Estudos apontam a existência de um possível sincronismo artificial entre a narrativa dos evangelhos e o mundo grecoromano. ${ }^{23}$ Esta teoria pode ser observada quando o autor do Evangelho de Lucas (3.1-2) cita: "E no ano quinze do império de Tibério César, sendo Pôncio Pilatos presidente da Judeia, e Herodes tetrarca da Galileia [...] sendo Anás e Caifás sumos sacerdotes, veio no deserto a palavra de Deus a João, filho de Zacarias". ${ }^{24} \mathrm{O}$ evangelista introduz seu relato sobre o início do ministério terreno de Jesus com acontecimentos políticos, colocando-o em uma consonância cronológica com o tempo romano, sendo talvez uma forma deliberada de justapor Jesus ao Império. Desse modo, os escritos de Lucas seriam uma resposta à propaganda imperial romana e à sua ideologia imperial e cultual. ${ }^{25}$ Entretanto, essa situação também é comum na literatura do Antigo Testamento, onde vários livros veterotestamentários iniciam-se com uma breve síntese do poder político local.

Contudo, quais seriam as intenções de Lucas, ao relatar o início do ministério de Jesus, com datações de reinados e imperadores? Seria realmente uma resposta subliminar ao Império regente? Por que as autoridades religiosas e políticas interpretaram Jesus, sua mensagem e seguidores, como uma possível ameaça ao seu poderio monopolizador?

\section{Origem do banditismo na palestina judaica}

Jesus de Nazaré entrou em cena na Palestina judaica num período em que a população enfrentava condições de vida difíceis no ambiente campestre. Diante desta

20 WIESE, 2009, p. 44.

21 GUERRA, Danilo Dourado. Messias e Heróis: a ressignificação do messianismo popular na comunidade joanina. Revista Fragmentos de Cultura-Revista Interdisciplinar de Ciências Humanas, v. 25, n. 3, p. 325-340, 2015. Disponível em: <http://revistas.pucgoias.edu.br/index.php/fragmentos/article/view/4192> Acesso em: 02 jul. 2019.

22 HORSLEY; HANSON, 2009, p. 9.

23 LIMA JÚNIOR, Francisco Chagas Vieira. Jesus é o filho de Deus (e o imperador não é): a simbolização de discursos antiimperialistas nos relatos evangélicos sobre o nascimento de Jesus. Veredas Favip-Revista Eletrônica de Ciências, v. 2, n. 1 e 2 , 2013 Disponível em: <http://veredas.favip.edu.br/ojs/index.php/veredas1/article/view/119> Acesso em: 02 jul de 2019.

24 BíBLIA. Novo Testamento. Marcos. Português. Bíblia Sagrada. Versão de João Ferreira de Almeida, Revista e Atualizada, 2 Edição. São Paulo: Sociedade Bíblica do Brasil, 1993. Cap. 14, v. 28. (ARA)

25 LIMA JÚNIOR, 2013, p. 29.

Protestantismo em Revista | São Leopoldo | v. 46, n. 01 | p. 134-147| Jan./jun. 2020

Disponível em: <http://periodicos.est.edu.br/index.php/nepp> 
realidade, os surtos de banditismo social eram quase inevitáveis. ${ }^{26}$ Qualquer voz, com espírito de liderança, que se levantasse no meio do povo e arrastasse multidões poderia ser julgada como perturbadora da "ordem e paz" garantida pelo governo. Baseado nisso, percebe-se aqui um ambiente revolucionário na Galileia de Jesus, onde fatidicamente acontece uma relação entre o Império Romano, movimentos de protestos e o próprio Jesus em sua prática e proposta. ${ }^{27}$

Compreender as frequentes resistências do contexto palestino demonstra que a figura de Jesus não fora tão rara, e também nos faz perceber formas sociais muito sugestivas por suas semelhanças com temas importantes na pregação e prática de Jesus. E, ainda, revela-nos um ambiente altamente politizado, repleto de tumultos, protestos e revoltas (abertas e ocultas). ${ }^{28}$

Diante de um quadro de injúrias e injustiças, nasce no âmago da natureza humana, principalmente dos oprimidos, o anseio por redenção e justiça. Esse sentimento não foi diferente em relação ao povo de Israel. Seu histórico de opressões e cativeiros reivindicava o surgimento e atuação de um "herói" enviado por Deus. Apesar de não tão frequente, nos escritos judaicos, a titulação dada a essa pessoa salvífica, enviada por Deus, era "Messias" (mashiach). Esse título era originalmente utilizado nos textos israelitas referindo-se a quem fosse ungido para uma função mediante o uso do óleo, seja sacerdotes, profetas e reis do antigo Oriente. ${ }^{29}$ "No contexto do Antigo Testamento, o termo (mashiach) se refere basicamente a um agente investido com uma função social específica. A unção com óleo separava socialmente um determinado indivíduo para o desempenho de uma tarefa especial, em caráter permanente ou temporário". ${ }^{30}$

A imagem emblemática desse rei ungido era o rei Davi. Por isso, não é de estranhar que os judeus esperavam que, no meio do seu povo, se levantasse um Messias semelhante ao próprio Davi. Provavelmente, outras pessoas manifestaram a expectativa davídica em torno de Jesus. Porém, nota-se que esse título (mashiach) também foi atribuído a outros. Observase no círculo dos discípulos essa esperança por meio da confissão messiânica de Pedro (Mc 8.29).

A raridade do termo Messias na literatura judaica da época não significa que não houvesse nenhuma expectativa de um líder real ungido. Em certos níveis da sociedade judaica existiu efetivamente a esperança de um agente real inspirado por Deus para trazer a libertação ao povo. Além do Messias raramente atestado, havia outras imagens que expressavam essa tradição de esperança, a mais notória das quais era de um rei davídico. ${ }^{31}$

26 HORSLEY; HANSON, 1995, p.69

27 AQUINO, Fernando Lopes de. Império romano, movimentos de protesto e Jesus: uma abordagem relacional segundo Richard Horsley. Oracula, v. 3, n. 5, p. 89-98, 2007. Disponível em: < https://www.metodista.br/revistas/revistas-ims/index.php/oracula/article/view/5895> Acesso em: 03 jul. 2019.

28 AQUINO, 2007, p. 96

29 GUERRA, 2015, p. 326.

30 SOUSA, Rodrigo F. O desenvolvimento histórico do messianismo no judaísmo antigo: diversidade e coerência. Revista USP, $\quad$ n. 82, p. 8-15, 2009. Disponível em: < https://www.revistas.usp.br/revusp/article/download/13746/15564> Acesso em 02 ago 2019.

31 HORSLEY; HANSON, 1995, p. 91.

Protestantismo em Revista | São Leopoldo | v. 46, n. 01 | p. 134-147| Jan./jun. 2020

Disponível em: <http://periodicos.est.edu.br/index.php/nepp> 
Nesse contexto de expectativa messiânica, na tentativa de resposta aos abusos cometidos pela aristocracia sacerdotal e ao Império Romano, emerge o fenômeno do banditismo social, que era largamente difundido e quase se tornou epidêmico. "Surgiram movimentos de aspiração escatológica, que determinaram o aparecimento de pretendentes ao cargo de Messias do povo. O clima de insatisfação social foi um terreno fértil para o surgimento de vários líderes populares que, mesmo sem pretensão, foram vistos como figuras messiânicas". ${ }^{32}$ Estes movimentos populares parecem ter sido característicos da sociedade judaica. Estão inclusos não só os movimentos messiânicos e proféticos, bem como a ocorrência de profetas populares que lembram os grandes profetas oraculares das Escrituras hebraicas. $^{33}$

Partindo dessa perspectiva política, pode-se observar semelhanças básicas entre o movimento messiânico de Jesus e os demais movimentos populares da Palestina, no século I d.C., contemporâneos ao d'Ele. O cuidado com as minorias da sociedade (pobres, órfãos, doentes e viúvas, por exemplo em Mt 23.14) está vinculado diretamente à solidariedade e ao comprometimento com a realidade de opressão e de dominação estrangeira enfrentada pelos judeus. $^{34}$

E, semelhantemente aos demais movimentos, o messianismo de Jesus apresenta um novo caminho diante da crise política e religiosa instaurada na Palestina, que permaneceu mesmo após o desaparecimento de seu líder principal. Essa relação indica um predicado de Jesus e de seu movimento que precisa ser levado em consideração: a sua imersão no contexto em que estava inserido, bem como o fato de ter liderado um movimento, em meio à dominação, apesar deste movimento não ter apresentado práticas semelhantes aos demais. ${ }^{35}$

Outra similaridade observada é que nesse ambiente de dominação, em paralelo ao movimento messiânico de Jesus, surgiram movimentos nacionalistas de cunho separatista, sob o comando de líderes carismáticos, que se sentiam chamados por Deus para serem instrumentos de libertação. O molde utilizado para a construção do messianismo tinha sua base nos grandes líderes políticos do passado. A ideia era voltar aos tempos da liberdade política israelita. Somente na condição de não submissão ao povo estrangeiro é que se pode prestar um culto perfeito ao Deus de Israel. ${ }^{36}$

Esses movimentos messiânicos de tipo popular precisam ser relidos a partir da margem social, ou seja, do olhar do oprimido. ${ }^{37}$ A mensagem de Jesus: "[...] é chegado o Reino de Deus" (Mt 10.7), "Meu reino não é desse mundo [...]" (Jo 18.36) e "Vou preparar-vos um lugar" (Jo 14.2) traz esperança para qualquer situação. Não era de se admirar que sua preleção foi nitidamente confundida com discursos de líderes rebeldes, que apregoavam tempos de paz e libertação da opressão do jugo religioso e político, sendo seus discípulos uma espécie de exército extraoficial para sua segurança e difusão de sua mensagem em caso de acidentes, prisão, assassinato ou morte.

32 VIEIRA, Ednaldo Rodrigues. Religião e compromisso social: Um estudo a partir do movimento de Jesus. Dissertação de Mestrado. Recife: UCP/PPG, 2007. p.37.

33 HORSLEY; HANSON, 1995, p. 11.

34 GUERRA, 2015 p. 330.

35 RIBEIRO, 2009, p. 47.

36 VIEIRA, 2007, p. 37.

37 GUERRA, 2015, p. 328.

Protestantismo em Revista | São Leopoldo | v. 46, n. 01 | p. 134-147| Jan./jun. 2020

Disponível em: <http://periodicos.est.edu.br/index.php/nepp> 


\section{O jesus bandido e salteador}

Soa um tanto quanto ousado, e por que não dizer quase profano, utilizar adjetivos criminosos para Jesus. Afinal, o homem simples de Nazaré, que trazia uma mensagem de amor, perdão e salvação, estava sempre com os pobres, viúvas e doentes (Mt 11.4-5; Mc 12.42-43; Lc 7.11-13), revelando uma contracultura de desapego aos valores materiais e construção de um relacionamento com Deus, aparentemente não apresentava nada de ameaçador. Porém, não era de maneira tão inocente e inofensiva que as autoridades religiosas e políticas o julgavam.

Sob o espectro político é possível notar situações pontuais na trajetória de Jesus que as autoridades governamentais e religiosas elegeram como uma possível ameaça local. Situações, discursos e atitudes, frequentemente interpretados pelo leitor bíblico como simples atos apologéticos em que Jesus defendia a fé que pregava, eram mal vistos pelos regentes políticos e religiosos.

A chegada de Jesus a Jerusalém é um marco no seu ministério. Ser recebido e aclamado Rei é um dos fortes indícios da expectativa messiânica e desejo de uma liderança real para libertação do povo: "Bendito seja o Rei que vem em nome do Senhor! Paz no céu! Glória nas alturas!" (Lc 19.38). Esta declaração indica os anseios do povo em relação a Jesus e suas dúvidas a respeito de Sua natureza e propósitos. Ele nunca se declarou como um rei político e estava sendo aclamado como tal na entrada de Jerusalém.

A ida de Jesus ao templo em Jerusalém culminou no episódio que inflamou ainda mais as autoridades religiosas a seu respeito (Mt 21.12-13; Mc 11.15-18). O templo já não era mais um local destinado apenas a finalidades religiosas, mas tornou-se um grande centro econômico e político. Jesus percebe claramente a posição opressora e centralizadora do templo, além da sua transformação em um local para transações bancárias (Lc 19.45). 38

As práticas econômicas já haviam se disseminado no campo religioso por meio da seleção das funções sacerdotais. Quem tivesse maior poder econômico podia adquirir o direito de ser nomeado sumo sacerdote. Ou seja, as classes com maior poder aquisitivo determinavam a ascensão ao poder sacerdotal. Com isso, o Império Romano assumia a liderança econômica e religiosa.39

Quando Jesus entrou no templo e expulsou os cambistas e vendedores (Mc 11.1519), ele propiciou um confronto direto com as autoridades acasteladas no templo. Estas autoridades, por sua vez, detectaram uma atitude banditista no pregador galileu, tornandose ele um perigo para os seus interesses. Afinal, mexer no templo é solapar a economia do Estado. Prejudicar a economia do "templo-estado" é abalar o prestígio político da sua administração interna, podendo estender-se a níveis maiores. Por isso, para a aristocracia judaica, o Jesus da Galileia tinha passado de todos os limites e devia ser eliminado o mais depressa possível. Afinal, ele havia mexido no centro do poder, em todos os sentidos. 40

38 VOLKMANN, Martin. Jesus "destruiu" o templo - a igreja o reconstruiu? Estudos Teológicos, São Leopoldo, vol. 30, n. 30, p. 244-255, 1990.

39 PORTO, Vagner Carvalheiro. Imagens monetárias na Judéia/Palestina sob dominação romana. Tese de Doutorado. Universidade de São Paulo. São Paulo: USP/PPG, 2007 p. 50.

40 VOLKMANN, 1990, p. 244-255.

Protestantismo em Revista | São Leopoldo | v. 46, n. 01 | p. 134-147| Jan./jun. 2020

Disponível em: <http://periodicos.est.edu.br/index.php/nepp> 
A situação de Jesus se agrava no episódio em que ele é questionado sobre o pagamento do tributo a César (Mc 12.13-17; Mt 22.15-22 e Lc 20.20-26). A interpretação desse episódio é objeto de controvérsia, porém, comumente ele é visto como uma distinção que Jesus estabelece entre Deus e Estado, em que se deve obedecer a ambos através da adoração (ao divino) e do pagamento dos impostos (ao governo regente). Porém a questão não se resume a esse duelo entre a quem obedecer ou não.

Essa concordância de Jesus ao pagamento dos impostos, e à obediência ao governo romano, não podem ser vistos como verdade absoluta. Diante da Palestina dominada, os judeus camponeses que o ouviam sairiam revoltados com essa resposta, pois ele estaria de acordo com a exploração tributária romana vigente, sendo omisso frente a realidade campestre. Ao invés disso, sua resposta causou surpresa e admiração em todos (Mc 12.17; Mt 22.22).41

A dominação romana outorgava posse e uso da terra às nações conquistadas, ou seja, a partir da dominação, o império dominador se tornava o proprietário daquele lugar. O poder do Império Romano, sob a Palestina judaica, era expresso principalmente pelos impostos. 42 Pagá-los era aceitar o poder, o senhorio e a apropriação romana. Concordar com esses impostos era o mesmo que descartar o que estava escrito no Salmo 24.1: "Do Senhor é a terra e a sua plenitude, o mundo e aqueles que nele habitam", trocando o Senhor dono da terra por Tibério (14-37 d.C).

\begin{abstract}
Jesus mostra-se extremamente crítico ao Império Romano. Ele afirma em Mc 10.4243: "Sabeis que aqueles que vemos governar as nações as oprimem, e os seus grandes as tiranizam. Mas entre vós não seja assim ..." Isto é um repúdio muito claro à política do Império! Em outra passagem, Mt 17.24-27, o assunto é o pagamento do imposto da didracma para o templo. Aí Jesus faz igualmente interessantes considerações sobre a natureza do domínio estrangeiro: "Ao entrar em casa Jesus antecipou-se lhe dizendo: Que te parece, Simão? De quem recebem os reis da terra tributos ou impostos? Dos seus filhos ou dos estranhos? Como ele respondesse "Dos estranhos", Jesus Ihe disse: "Logo, os filhos estão isentos"! (Mt 17.25-26). Jesus, neste trecho, reconhece a prática usual: os tributos são exigências que se faz a estranhos, a quem a gente dominou e venceu. Simultaneamente, porém, é inegável que o juízo que Jesus faz dessa cobrança de tributo é altamente negativo: exigência de tributo é exercício de tirania, não tem nada a ver com o exercício de soberania daqueles governantes que se entendem como pais do povo, a quem têm a tarefa e o desejo de servir e por quem também estão dispostos a se sacrificar em caso de necessidade. ${ }^{43}$
\end{abstract}

A tensão da liderança política sobre o povo, oriunda das preocupações da aristocracia religiosa entre Jesus e a liderança judaica, ganha um novo cenário e se agrava na narrativa dos evangelhos no relato de sua prisão (Mc 14.48). Notam-se algumas variações na tradução do texto de versão para versão em português. Por exemplo, na Nova Versão Internacional utilizase a expressão: "liderando alguma rebelião", já na versão da Bíblia de Jerusalém e na Almeida Revista e Atualizada, usa-se o termo: "ladrão" e "salteador", respectivamente: "Disse Jesus:

41 WEGNER, Uwe. O que fazem os denários de César na Palestina? Estudos Teológicos, v. 29, n. 1, p. 87-105, 1989.

42 SILVA, Gilvan Ventura; MENDES, Norma Musco. Repensando o Império Romano: perspectiva socioeconômica, política e cultural. Mauad Editora Ltda, 2006.

43 WEGNER, 1989, p. 93-94.

Protestantismo em Revista | São Leopoldo | v. 46, n. 01 | p. 134-147| Jan./jun. 2020

Disponível em: <http://periodicos.est.edu.br/index.php/nepp> 
Estou eu chefiando alguma rebelião, para que vocês venham me prender com espadas e varas?" 44 . "Jesus, tomando a palavra, disse: "Como a um ladrão, saístes para prender-me como espadas e paus!"45. "E, respondendo Jesus, disse-Ihes: Saístes com espadas e varapaus a prender-me, como a um salteador?". 46

No texto original, em grego, o vocábulo lēstēs pode ser traduzido como ladrão, salteador, rebelde e criminoso ${ }^{47}$, sendo uma palavra comumente utilizada no Novo Testamento (15 vezes) em situações como em Mateus 21.13: “[...] a minha casa será chamada casa de oração, vós, porém a transformai em covil de salteadores".

A palavra lēstēs era utilizada, no Mundo Antigo, para soldados ou mercenários que possuíam um direito implícito ao saque, normalmente militares indisciplinados. Posteriormente foi empregada para ladrões, bandidos etc., com um uso implícito da força. ${ }^{48}$

Josefo ${ }^{49}$ usa o termo para os zelotes, os quais, sob líderes como Ezequias e Judas da Galileia, se revoltam contra o domínio romano, talvez com pretensões messiânicas. Para muitos judeus, os zelotes são patriotas antes de bandidos, mesmo que muitas das vezes tirem, do seu próprio povo, aquilo de que precisam". ${ }^{50}$

No entanto, Josefo ${ }^{51}$ aceita a visão romana, pois embora os romanos executem os zelotes como criminosos políticos (por crucificação), eles desdenhosamente os descrevem como bandidos. $\mathrm{O}$ autor ${ }^{52}$ reserva esse termo para indivíduos pertencentes a facções zelotes que, na sua ótica, abusam da causa religiosa. ${ }^{53}$ Porém, observa-se que a palavra lēstēs apresenta alguns significados peculiares, dependendo de onde ela é empregada.

Na história do Bom Samaritano, o termo lēstai (plural de lēstēs) (Lc. 10.30,36) talvez não se refira a bandidos no sentido geral, e tenha o significado rabínico de zelotes. A vítima é um judeu. Mas não é morto, e suas feridas talvez sejam oriundas de uma possível resistência ao ataque. Quando os zelotes roubavam para levantar suprimentos para si mesmos, sabe-se que não tomavam dos seus compatriotas mais do que o necessário. Se os lēstai na história são zelotes, este fato dá mais razão de ser à resposta de Jesus à pergunta do escriba acerca do próximo, pois os fariseus

44 BÍBLIA. Novo Testamento. Marcos. Português. Bíblia Sagrada. Nova Versão Internacional, Edição. São Paulo: Editora Vida, 2011. Cap. 14, v. 28. (NVI)

45 BíBLIA. Novo Testamento. Marcos. Português. Bíblia de Jerusalém. Nova Edição, Revista e Revisada. São Paulo: Paulus, 2002. Cap. 14, v. 48 (BJ)

46 BÍBLIA. Novo Testamento. Marcos. Português. Bíblia Sagrada. Versão de João Ferreira de Almeida, Revista e Atualizada, 2 Edição. São Paulo: Sociedade Bíblica do Brasil, 1993. Cap. 14, v.28. (ARA)

47 HAUBECK, Wilfrid; SIEBENTHAL, Heinrich Von. Nova Chave linguística do Novo Testamento grego: Mateus Apocalipse. 1a ed. São Paulo Hagnos, 2010. p. 377.

48 KITTEL G.; FRIEDRICH, G. Dicionário Teológico do Novo Testamento: Volume 1. 1a ed. São Paulo: Cultura Cristã, 2013. p. 590.

49 JOSEFO, F. História dos Hebreus: obra completa. Rio de Janeiro: Casa Publicadora das Assembleias de Deus, 2007, $1568 \mathrm{p}$.

50 KITTEL; FRIEDRICH, 2013, p 590.

51 JOSEFO, 2007.

52 JOSEFO, 2007.

53 KITTEL; FRIEDRICH, 2013, p 590.

Protestantismo em Revista | São Leopoldo | v. 46, n. 01 | p. 134-147| Jan./jun. 2020

Disponível em: <http://periodicos.est.edu.br/index.php/nepp> 
estavam constantemente insistindo que Jesus declarasse Sua atitude para com o movimento nacionalista. ${ }^{54}$

Se o termo lesstai também puder ser aplicado no sentido de "zelote", no episódio da purificação do templo, Jesus está dizendo que as autoridades que ministravam nele, mediante as suas atividades, estavam abrindo o caminho para o edifício ser transformado em "fortaleza dos zelotes". ${ }^{55}$ Entretanto, é importante destacar que o termo "zelote", com conotações político-revolucionárias, emerge no ano 6 d.C., após a deposição de Arquelau, quando a Judeia passou a ser uma procuradoria romana. Uma insurreição oriunda dos possíveis zelotes é datada de 47 d.C, porém o seu protagonismo é no confronto entre judeus e romanos em 70 d.C. ${ }^{56}$

Neste ambiente de tensões, no episódio da prisão de Jesus, ele quer saber por que os seus inimigos, fortemente armados, agora o tomam por um lēstēs, um "bandido" ou "revoltoso". O dito de Jesus para aqueles que o prendem em Marcos 14.48 e Mateus 26.55 traz uma clara referência messiânica. Rejeitar a reivindicação de Jesus é classificá-lo como os líderes revolucionários zelotes. Pilatos, na verdade, deixa o povo escolher entre Barrabás, o combatente pela liberdade, e Jesus de Nazaré, como se ambos fossem homens de igual caráter, mesmo estando ele convencido da inocência do líder nazareno. ${ }^{57}$

Observa-se o emprego desta mesma palavra nos relatos da crucificação, quando dois lēstaí foram crucificados com Jesus. O título, sobre a cruz, identifica Jesus como um líder zelote, embora entregue por seu próprio povo. Ele é um a quem o povo rejeita. Porém, esta palavra provavelmente pode ser traduzida como "bandidos" ao invés de "revolucionários", tendo em vista o emprego de kakourgoi, "criminosos", na passagem paralela em Lc 23.33. ${ }^{58}$

Jesus de Nazaré, possível bandido social para a aristocracia judaica, no seu período de atuação na Palestina, inspira o movimento que deu origem ao cristianismo. Ele foi violentamente perseguido e sumariamente executado através da crucificação, porque as suas reivindicações, sob a forma de pregação, também negavam e afrontavam enfaticamente os poderes imperiais romanos e os poderes oligárquicos judaicos como legítimos. ${ }^{59}$

É uma ironia intrigante que, tendo se recusado deliberadamente a utilizar métodos políticos e tendo rejeitado uma interpretação de Sua missão que faria Dele um líder de uma agitação contemporânea contra Roma, Jesus tenha sido executado sob a acusação de planejar uma revolta contra o Império Romano. Isso é em parte um reflexo da completa incapacidade dos líderes de Sua nação e do representante de Roma no sentido de entendê-Lo ${ }^{60}$.

Os propósitos do movimento messiânico de Jesus são claramente confundidos com movimentos de banditismo social na Palestina, devido ao seu surgimento em meio a uma

54 COENEM, Lothar; BROWN, Collin. Dicionário Internacional de Teologia do Novo Testamento. Tradução de Gordon Chown. 2 ed. São Paulo: Vida Nova, 2000. p.795.

55 COENEM; BROWN, 2000, p.795.

56 BRUCE, F. F. História do Novo Testamento. 1a ed. São Paulo: Vida Nova, 2020.

57 KITTEL; FRIEDRICH, 2013. p. 590

58 COENEM; BROWN, 2000, p.795.

59 LIMA JUNIOR, 2013, p. 128

60 LATOURETTE, K. S. Uma História do Cristianismo: Volume 1: até 1500 a.D. 1ạ ed. São Paulo: Hagnos, 2006. p.71.

Protestantismo em Revista | São Leopoldo | v. 46, n. 01 | p. 134-147| Jan./jun. 2020

Disponível em: <http://periodicos.est.edu.br/index.php/nepp> 
sociedade oprimida e ao mesmo tempo esperançosa da chegada de um líder que lutasse pelos direitos do seu povo. "Pode-se dizer que Jesus de Nazaré implodiu toda e qualquer compreensão messiânica do seu tempo, e certamente também do nosso tempo". ${ }^{61}$ O Messias revolucionário que invade o templo, expulsando os comerciantes e cambistas, gerando vislumbres na população, de uma possível insurreição popular, que culminasse em uma reforma religiosa é completamente distinto daquele se abstém de questões populares políticas, como o pagamento de tributos ao Império Romano (Mc 12.13-17).

A visão de Jesus, como o Messias prometido por Deus, traz uma nova abordagem ao seu messianismo, sem rejeitar Israel nem a sua esperança. "Este contexto multifacetado de concepções messiânicas, no judaísmo do início do primeiro século, reveste-se de particular importância para entender a ação de Jesus e o modo como os seus contemporâneos o interpretaram". ${ }^{62} \mathrm{O}$ rompimento de novos e insuspeitáveis horizontes, revestidos não apenas da tradição do passado, mas sobretudo da Sua própria vida e palavra, revelam Jesus como o Cristo dos pobres, oprimidos, subversivos, mas também de toda a humanidade. ${ }^{63}$

\section{Considerações finais}

Com o passar dos anos, observa-se que o contexto histórico-político-social e a objetividade revolucionária de Jesus vêm ganhando historicidade, protagonismo e elementos importantes para compreender e interpretar a narrativa dos evangelhos sobre ele. Essas ferramentas e discussões também fazem parte da hermenêutica bíblica e estudos teológicos.

As pesquisas na área do Novo Testamento, desenvolvidas nos últimos anos, revelam uma releitura sociológica e antropológica das narrativas Neotestamentárias. Fica cada dia mais evidente a necessidade de investigar o "Jesus Histórico", não para diminuir ou questionar a sua divindade, mas elucidar significados obscuros nos seus discursos, para compreender melhor tanto o texto como a Palestina do século I. d.C.

Dentro desta perspectiva histórica-política, a leitura sociológico-epistemiológica deste trabalho, sobre os acontecimentos narrados no NT, mostraram-se úteis para a pesquisa, externando que existem vários caminhos para compreender os fatos, além da interpretação convencional.

Evidenciou-se nesse trabalho a ligação direta entre o Jesus histórico e a esperança messiânica judaica, tornando essas duas dimensões inseparáveis para a compreensão do texto sacro. Observa-se um Jesus que não só fez pregações de cunho religioso, mas personificou alguém que viveu e falou da realidade social da sua época. Sem esta interligação históricopolítica, trata-se de um enredo complexo de ser analisado.

Um fato importante, emergido na discussão desse trabalho, foi a importância das massas populares nos acontecimentos históricos. As "pessoas simples" sempre tiveram importância na história da humanidade e também na "história teológica". Por este motivo, caso a teologia aspire ser relevante e queira impactar a transformação da sociedade, não pode

61 WIESE, 200, p. 43.

62 CARVALHO, 2000, p. 49.

63 CARVALHO, José Ornelas. Origem e evolução do messianismo em Israel. Revista Didaskalia, n 30, 2000. p. 49.

Protestantismo em Revista | São Leopoldo | v. 46, n. 01 | p. 134-147| Jan./jun. 2020

Disponível em: <http://periodicos.est.edu.br/index.php/nepp> 
ignorar essas "pessoas simples". Isso respinga também na popularização do conhecimento teológico junto a essa gente simples e tão preciosa para as comunidades cristãs. ${ }^{64}$

Porém, Jesus não buscava uma revolução política ou econômica. Sua mensagem não dava importância às distinções entre judeus e gentios, homens e mulheres, escravos e livres, ricos e pobres. Essas diferenças mal chegavam a ser atacadas na teoria, e simplesmente eram ignoradas na prática. Era de se esperar que a sua execução político-religiosa fosse semelhante ao que ocorreu com João Batista. O que ele fazia e dizia era tão inaceitável tanto no século I, como nos dias de hoje. ${ }^{65}$

Espera-se que esse trabalho possa contribuir para o reconhecimento da relevância sobre as pesquisas a respeito do Jesus histórico, no seu contexto político-social, gerando reflexões sobre a necessidade de análises e investigações sobre as realidades dos grupos sociais da época bíblica para compreensão do texto sagrado.

\section{Referências}

AQUINO, Fernando Lopes. Império romano, movimentos de protesto e Jesus: uma abordagem relacional segundo Richard Horsley. Oracula, v. 3, n. 5, p. 89-98. Disponível em: <https://www.metodista.br/revistas/revistas-ims/index.php/oracula/article/view/5895> Acesso em: 03 jul. 2019.

BÍBLIA. Novo Testamento. Marcos. Português. Bíblia de Jerusalém. Nova Edição, Revista e Revisada. São Paulo: Paulus, 2002. Cap. 14, v. 48 (BJ)

BíBLIA. Novo Testamento. Marcos. Português. Bíblia Sagrada. Nova Versão Internacional, Edição. São Paulo: Editora Vida, 2011. Cap. 14, v. 28. (NVI)

BÍBLIA. Novo Testamento. Marcos. Português. Bíblia Sagrada. Versão de João Ferreira de Almeida, Revista e Atualizada, 2 Edição. São Paulo: Sociedade Bíblica do Brasil, 1993. Cap. 14, v. 28. (ARA)

CARVALHO, José Ornelas. Origem e evolução do messianismo em Israel. Revista Didaskalia, $\mathrm{n}$ 30, 2000. Disponível em: < http://repositorio.ucp.pt/bitstream/10400.14/18480/1/V03001029-051.pdf> Acesso em: 08 jul. 2019.

em: 02 jul de 2019.

FONSECA, Luís Fernando. A secularização da utopia: as raízes do pensamento igualitário na cultura judaico-cristã. Tese de Doutorado. São Leopoldo: EST/PPG, 2018.

GUERRA, Danilo Dourado. Messias e Heróis: a ressignificação do messianismo popular na comunidade joanina. Revista Fragmentos de Cultura-Revista Interdisciplinar de Ciências Humanas, v. 25, n. 3, p. 325-340, 2015. Disponível em: <http://revistas.pucgoias.edu.br/index.php/fragmentos/article/view/4192>. Acesso em: 02 jul. 2019.

64 WIESE, 2009, p.45

65 CROSSAN, John Dominic. O Jesus histórico: a vida de um camponês judeu do mediterrâneo. Tradução de André Cardoso. Rio de Janeiro: Editora Imago, 1994. p.12

Protestantismo em Revista | São Leopoldo | v. 46, n. 01 | p. 134-147| Jan./jun. 2020

Disponível em: <http://periodicos.est.edu.br/index.php/nepp> 
HAUBECK, Wilfrid; SIEBENTHAL, Heinrich Von. Nova Chave linguística do Novo Testamento grego: Mateus - Apocalipse. 1a ed. São Paulo: Hagnos, 2010.

HOBSBAWN, E. Primitive Rebels: studies in archaic forms of social movement in the 19th and 20th centuries. Manchester, 1959.

HORSLEY, Richard A.; HANSON, John S. Bandidos, Profetas e Messias: Movimentos Populares no Tempo de Jesus. 1a ed. São Paulo: Paulus, 1995.

KITTEL G.; FRIEDRICH, G. Dicionário Teológico do Novo Testamento. Volume 1. 1a ed, Cultura Cristã, São Paulo, 2013.

LATOURETTE, K. S. Uma História do Cristianismo: Volume 1: até 1500 a.D. 1a ed. São Paulo: Hagnos, 2006.

LIMA JÚNIOR, Francisco Chagas Vieira. Jesus é o filho de Deus (e o imperador não é): a simbolização de discursos antiimperialistas nos relatos evangélicos sobre o nascimento de Jesus. Veredas Favip-Revista Eletrônica de Ciências, v. 2, n. 1 e 2, 2013. Disponível em: <http://veredas.favip.edu.br/ojs/index.php/veredas1/article/view/119> Acesso

RIBEIRO, Ari Luís do Vale. Jesus e os movimentos messiânicos. Revista de Cultura Teológica, $\mathrm{n}$. 66, p. 27-54, 2009. Disponível em: < http://www.scielo.br/pdf/his/v23n1-2/a12v2312.pdf> Acesso em: 07 jul 2019.

ROCHA, Ivan Esperança. Dominadores e dominados na Palestina do século I. História (São Paulo), p. 239-258, 2004. Disponível em: <http://www.scielo.br/pdf/his/v23n1-2/a12v2312> Acesso em: 02 jul 2019.

STEGEMANN, Ekkehard W; STEGEMANN, Wolfgang. História Social do Protocristianismo: os primórdios do judaísmo e as comunidades de Cristo no mundo mediterrâneo. 1a ed. São Paulo; São Leopoldo: Paulus; Sinodal, 2004.

VIEIRA, Ednaldo Rodrigues. Religião e compromisso social: Um estudo a partir do movimento de Jesus. Recife: UCP/PPG, 2007.

WIESE, Werner. Conflitos sociais e esperança messiânica na palestina judaica o século I d.c. Vox Scripturae. 12:1, FLT, 2009. p.25-50.

ZITZKE, ÂNGELA. Amor Divino na Carta aos Romanos: análise histórica, exegética e sistemática da entrega de Cristo em textos selecionados. (Tese de Doutorado). São Leopoldo: EST/PPG, 2011. 